завданням наукового пошуку є визначення структурних складових суб'єктивного благополуччя особистості в шлюбі, його функцій і рівнів прояву. Дослідження проводилося на основі анкетування, психодіагностичних методик вивчення задоволеності шлюбом, самореалізації особистості в сім'ї (на операціональному рівні та рівні цінностей і рольових установок), соціально-психологічної адаптованості, узгодженості сімейних цінностей i рольових очікувань в шлюбі. Показано, що суб'єктивне благополуччя особистості в шлюбі - це поліфункціональне інтегральне соціально-психологічне утворення, в структуру якого входять когнітивно-оцінна, мотиваційно-ціннісна, емоційно-поведінкова складові. Встановлено, що провідними функціями суб'єктивного благополуччя є регулятивна, прогностична та розвиваюча. Виділено соціально-психологічні фактори суб'єктивного благополуччя особистості в шлюбі: соціально-психологічна адаптованість і толерантність; ціннісноорієнтаційна єдність 3 партнером і благополуччя шлюбних відносин; задоволеність шлюбом; узгодженість ступенем значущості сімейних цінностей в емоційній, інтимно-сексуальній, господарсько-побутовій, батьківськовиховній сферах, сферах особистісної ідентифікації та соціальної активності; можливість саморозвитку, самовдосконалення і особистих досягнень в поєднанні з домінуванням сімейних цінностей; визначеність і несуперечливість рольових очікувань і рольових домагань, збіг уявлень про рольову поведінку; низький рівень конфліктності у взаємодії подружжя (підтримка, емоційний комфорт, культура спілкування). Основним напрямком подальших досліджень розглядається вивчення особливостей переживання суб'єктивного благополуччя в шлюбі на різних етапах проходження стадій життєвого циклу сім'ї.

Ключові слова: особистість, благополуччя, шлюб, соціально-психологічні чинники, суб’єктивне благополуччя.

Submitted on January, 10, 2017

Reviewed by Doctor of Psychology, prof. M. Toba

UDC: 159.922 .7

DOI: https://doi.org/10.24195/2414-4665-2017-1-2

Nataliia Volianiuk,
Doctor of Psychology, professor,
Head of the Department of Psychology and Pedagogy,

Olha Bokovets, post-graduate student, Department Psychology and Pedagogy, National Technical University of Ukraine "Igor Sikorsky Kyiv Polytechnic Institute", 37, Peremogy Avenue, Kyiv, Ukraine

\title{
PSYCHOLOGICAL STRUCTURE OF INNOVATIVE POTENTIAL OF A PERSONALITY
}

The article is devoted to the theoretical substantiation of the psychological structure of the innovative potential of a personality. The concept of the "innovative potential of a personality" is reviewed from the perspective of two phenomena, namely "innovation" and "potential". The innovation is considered as a result of innovative activity, which includes creation, development and use of the new. The potential is conceived as a system of opportunities, productive forces, reserves and resources, the extent of which, hypothetically, to a greater extent depends on the personality, and to a lesser extent - on external factors. The innovative potential is a dynamic integrated set of social and psychological characteristics of a personality that determines his/her capacity for creation, development and use of the new, and as a result of its implementation it will fulfill the needs of the society and will produce further socialized development of a personality. The following structural components of the innovative potential of a personality are highlighted: "environmental" (social, material and spiritual) and personal (motivational and value, cognitive, creative, emotional and volitional, and regulatory) resources.

Keywords: innovation, potential, resource, personality, structure.

\section{Introduction}

Modern society is often called the society of knowledge-based economy driven by knowledge, which is concentrated in human capital assets. At the same time, the ability to generate, use and distribute new knowledge determines the creation of highly qualified services and products, thereby ensuring the growth and competitiveness of such economy on the international scene. Consequently, there occurs a gradual transition to the innovative development of society driven by the innovative personality who has the knowledge of current importance, flexibility and critical thinking, creativity and high adaptive abili- 
ties. This personality has the resources and abilities, the discovery and actualization of which significantly affect the degree of the development of his/her innovative potential, and therefore - the progress of the society. Active investigating of the conditions, specificity, determinants of the development of the innovative potential of a personality are caused by practical needs of human society in the search for potential innovators who are able to create the new in science and technology. Due to the importance of the role of the innovative potential, there is a need for a differentiated consideration of its constituent parts that mediate the relationship between individual properties of the psyche of the subject and coordinate its activity in accordance with socially and individually significant purposes. Therefore, the innovative potential of a personality is considered according to its actualization in technically-oriented and entrepreneurial projects. There is a strong possibility that the structure of the innovative potential combines those mental formations, which are able to organize and coordinate various forms of interaction of the subject with reality. In the development of ideas about the innovative potential, the following terms are highlighted: as intellect, needs and motives, spiritual and value formations, emotions and will. However, until now the specificity of the innovative potential is investigated fairly fragmentarily.

The article is aimed at defining structural components of the innovative potential of a personality and justifying its psychological structure.

The following methods were used in the study: analysis, synthesis, comparison, generalization and systematization of modern scientific resources on the issue of the formation and development of the innovative potential of a personality.

\section{Discussion}

The concept "innovative potential of personality" should be considered in the light of two phenomena, namely "innovation" and "potential". They are the subject of research of national and foreign scientists in various fields and areas of activity, but there is still no clear unambiguous definition of both terms, while these categories can be used in different contexts and meanings. The choice of a category depends on a specific purpose.

The etymology of this concept suggests the expediency of revealing the main characteristics of the concepts of innovation and potential. The term "innovation" should be considered first. The innovation is usually conceived as renovation, change, novelty; new technology or choice that qualitatively surpasses previous ones or significantly differs from them; activities aimed at creating fundamentally new or improved products, technologies, services, etc. As is well known, the concept of innovation has appeared in economics. In 1912, this term was introduced into scientific circulation by Y.A. Schumpeter [23]. From his point of view, the innovation is a new combination, novelty, which basically means recombination of new means of production. In fact, the innovation is a factor of dynamic changes in the economic system.
In modern economic literature, the innovation is understood not only as a process of converting opportunities into new ideas or products, but also as a successful result of their implementation in the market. The concepts of "novelty", "pioneer work" and "modernization" are often used as synonyms to the category of "innovation". However, there are some differences between them: novelty is a new idea or product, which becomes an innovation only during implementation; pioneer work is a result of practical development of a novelty, i.e. the process of implementation of new products, technologies, services, etc.; modernization is a change adapted to modern requirements, process of improvement, assignment of modernity to an object, improving it via renewal, while innovation is not just an introduction as a phenomenon, but also the result of the innovative process that fulfills social needs.

The innovative process, as a gradual transformation of innovative ideas into a new product or service, can be divided into two main stages, namely the creation of innovations and commercialization of innovations. The creation of innovations involves fundamental and applied research studies (new ideas, abilities, conceptual solutions) and development (new products, processes, services, etc.). The commercialization of innovations means their implementation and diffusion (spreading) in production [12]. In other words, the innovation process is a purposeful activity of creation, development and use of the new. The perception and implementation of innovations are characterized by personality innovativeness [24] which goes into the sphere of social sciences, psychology in particular.

In economics, the innovation is interpreted as the result of the innovation process, but in psychology - as a result of creativity, which means revealing the personality's capabilities and creating new, original and unique ideas and approaches of social significance.

The study also requires the consideration of the second component of the phenomenon "innovative potential", namely "potential". Academic Explanatory Dictionary of the Ukrainian Language provides the following definition of the term "potential": (from the Latin word potentia): "hidden abilities, forces for any activity that may appear under certain conditions" [20, 402]. However, the Great Dictionary of the Modern Ukrainian Language interprets the concept "potential" as a combination of all available means, opportunities, productive forces, etc. that can be used in a particular field, region, area [3, 902].

What is common in these definitions is the categories of "force" and "ability" or "means", but, in our opinion, it is not enough to reveal just the essence of the definition of the concept "potential" in the context of our study. The key category that combines the force, the ability, and the means is a "reserve" and/or "resource". The reserve is a "stock of anything that is specifically preserved when necessary"; "still unused opportunities, means to accomplish something; a source where new forces come from for something" [20, 486]. That is, the reserve is an unused or lost resource or opportunity, while the resource is a 
"stock of anything that could be used if necessary; means, opportunity that can be used if necessary" [21, 515].

The review of scientific sources $[14 ; 17 ; 19 ; 16]$ shows that from a psychological point of view, resources are considered as external and internal abilities of a personality, i.e. such a "life support" that providing basic human needs (physiological, safety, social, respect, selfexpression) is at a human's disposal. Accordingly, the resources of a personality are divided into "environmental" (instrumental, emotional and moral support from the social environment of the personality) and personal (knowledge, abilities, skills, capabilities, competencies, human experience etc.). However, this division is quite arbitrary, as both external and internal resources are in dialectical unity, being determined by the processes of interiorization and exteriorization.

External abilities as "environmental" resources are all "the external" that ensures the success of the processes of individualization, socialization and professionalization of a personality (social attitudes, expectations, position, status, role) [13]; this is wealth, social status (roles) and social relationships which provide support to the society, help people from outside [16]. If the environment is assumed as a set of social, material and spiritual living conditions of a personality, which influence his/her development, then the "environmental" resources can be divided into social (individualization, socialization, education, professionalization, communication, etc.), material (wealth and material resources) and spiritual (cultural values, education, etc.). Focusing on the external resources, it should be noted that they include all that is immanently inherent to the individual from birth, is constantly renewed and reflected in the system of physical, mental and social qualities that undoubtedly relate to the personal development [8].

The internal abilities as personal resources are everything that is peculiar to a personality and emphasizes his/her individuality: personality traits, abilities, values and other qualities that constitute an integral system, which is continually renewing and developing [10]; it is the psychological personality potential, character and skills of the individual that help him/her from within [16]; a set of developed psychosocial, communicative, motivational, characterological, reflective, intellectual, psychophysiological, psychosomatic properties, which are concentrated in relevant substructures [9]; personal qualities and attitudes that affect the regulation of behavior, providing a high level of personality's activity [2]; intellectual abilities, qualities, knowledge, capabilities, skills, and interests, social guidance, value orientation and mentality which define types of behavioral responses and provide an opportunity to transform motivation into real activity [11].

The system of internal resources, ensuring the integral process of personality's life, includes the following subsystems: biogenetic (concerned with heredity), physiological (health, peculiarities of body constitution, physical endurance, age, gender, etc.), psychological (the level of intellectual development, peculiarities of the emotional sphere, volitional characteristics, etc.) [18]. In the context of our study, the psychological subsystem of the internal resources of a personality should be considered in details.

The review of the research studies $[4 ; 5 ; 8 ; 9 ; 13 ; 15]$ devoted to the psychological potential of a personality reveals the following components of subsystems of the internal resources of the innovative potential of a personality.

Firstly, motivational and value resources, which are determined by the peculiarities of motivational and value sphere of the individual (makings, needs, inclinations, interests, aspirations to the creation of the new, readiness to abandon the stereotypes, value orientations, axiological attitude towards innovation, etc.). The motivational and value resources determine the ability of the individual for self-determination, which is possible due to, among other things, the optimistic view on his/her own abilities. In fact, it is the capability of the personality to actualize individual abilities that are found in self-disclosure and self-development strategy focused on the future [22]. The motivational and value resources (primarily conscious analysis and assessment of one's own abilities) significantly affect the efficiency of the use of the individual's resources in general [18].

Secondly, cognitive resources, which are caused by the peculiarities of the cognitive sphere of the individual (perception, sensation, memory, thinking, imagination, etc.); it is a system of intellectual and cognitive abilities of the individual's psyche which organize a strategy for the effective acquisition and use of information needed for decision-making [6,9]. The cognitive resources are essentially a manifestation of general intelligence of a personality. But in the context of our study, a significant role is played by flexibility of thinking, because without it the generating of new ideas would be complicated. The perception of innovations that include both the attitude of the individual towards work under new conditions related to the change of the very activity and self-perception of innovations as necessary changes are also important [8].

Thirdly, creative resources as the integrated set of abilities, characteristics, personality traits enable and prepare a personality for accomplishing effective creative activity. The creative potential of a personality is formed as a meaningful resultant of two major tendencies, which are antinomic by nature, namely of stereotype and originality [9], that, ultimately, is a creative feature. Creativity as a non-standard and non-traditional approach to life involves capitalization on the latent possibility, use of unusual and unique ways of solving problems, production of fundamentally new ideas [1].

Fourthly, emotional and volitional resources, which are specified by the peculiarities of emotional and volitional sphere of a personality (emotions, feelings, mood, will, volitional qualities, etc.) and provide the fulfilling and realization of the personality's potential (confidence, commitment, rigor, hard work, ability to manage oneself in the process of innovative activity, etc.) [13]. 
Fifthly, regulatory resources, which are a set of personality traits that determine his/her ability for selfdetermination (activity, performance, endurance, etc.). They relate, firstly, to the fundamental limitation of resource properties of the psyche, and secondly, to the possibility of flexible allocation and reallocation by a personality of his/her resources among different channels of regulation and responsible behavior [6]. The regulatory resources mean the ability of a personality to be consistent with stable internal criteria and landmarks in his/her life and maintain the stability of activity and sense orientation under external pressure and under changing conditions [7]. That is, the regulatory resources are characterized by the ability to renew and use potential abilities if necessary.

Hence, the potential of a personality is characterized by the combination of internal and external resources, the degree of development of which, hypothetically, to a greater extent depends on the personality, and to a lesser extent - on external factors. It is this conceptual position that underlies the psychological structure of the innovative potential of a personality created by us (Fig. 1).

It should be noted that the potential is considered not as a state of temporarily unused resources but as the increasing readiness to solve increasingly complex tasks $[19,226]$. A number of researchers $[4 ; 8 ; 13 ; 19]$ state that the potential has two quality conditions provided by the resources of a personality: potential and actualized. That is, the potential of a personality is accumulated in a hidden - potential form (natural features, properties and human abilities, social opportunities, etc.), and then, due to circumstances, it becomes apparent in an actual form (qualitative transformations of a person, external manifestations of regulation and behavior, etc.). Herewith, the processes of interiorization and exteriorization take on the role of psychological mechanisms of potentiationactualization [9].

Having considered the meaning of the concepts "potential" and "innovation" the following definition of the "innovative potential of a personality" can be given: it is a certain system of internal and external resources which defines the abilities, skills and capabilities of a personality to perform innovative activity. In a narrow sense, it is a dynamic integrated set of social and psychological characteristics of a personality, which determines his/her capacity for creation, development and implementation of the new, the implementation of which will fulfill the needs of the society and produce further socialized development of the personality.

Having reviewed a number of research papers on the problem, we have systematized and generalized psychological components of the innovative potential of a personality (Fig. 1).

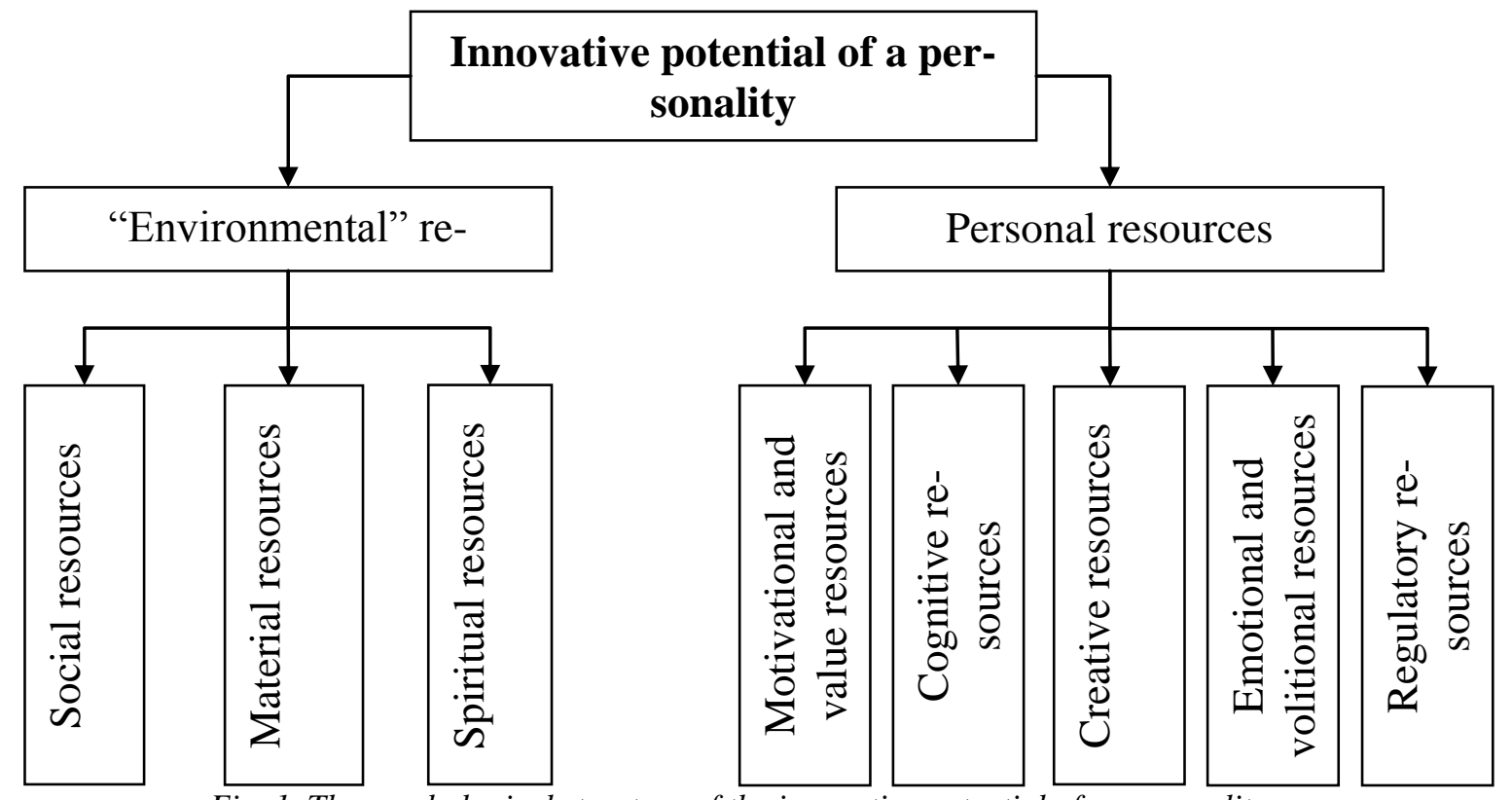

Fig. 1. The psychological structure of the innovative potential of a personality

In the Figure 1, it is shown that the innovative potential of a personality includes the "environmental" and personal resources. In turn, the "environmental" resources are divided into social, material and spiritual. They are associated with the influence of the social environment, conditions of education, training, etc. The structure of the personal resources consists of five components: motivational and value, cognitive, creative, emotional and volitional, and regulatory. The confunction of the internal resources is the integrated dynamic system of abilities, productive forces and reserves, which is constantly being consumed, resumed and developed, namely the innovative potential of a personality. The "environmental" and personal resources of various levels, ensuring the realization of the innovative potential, determine the purposes and the way they are set by a potential innovator, as well as define peculiarities of their achievement.

\section{Conclusions}

Hence, the innovative potential is a dynamic system of external and internal renewable resources, which 
means the ability of a personality to identify the "new", generate new ideas and implement them. The psychological structure of the innovative potential of a personality includes the "environmental" (social, material and spiritual) and personal (motivational and value, cognitive, creative, emotional and volitional, and regulatory) resources. These circumstances determine the relevance of

\section{REFERENCES}

1. Gabora, L. (2013). Psychology of Creativity. In Elias G. Carayannis (Ed.) Encyclopedia of Creativity, Invention, Innovation, and Entrepreneurship, 1515-1520 [in English].

2. Bodrov, V. A. (2006). Problema preodoleniya stressa. Chast 2. Processy i resursy preodoleniya stressa [Coping stress problem part II. Coping stress processes and resources]. Psikhologicheskiy zhurnal - Psychological journal, 2, 113-123 [in Russian].

3. Busel, V.T (2003). Velykyi tlumachnyi slovnyk suchasnoi ukrainskoi movy [Great Dictionary of the Modern Ukrainian language]. Kyiv; Irpin: VTF Perun [in Ukrainian].

4. Volyanyuk, N. Yu., \& Lozhkin, H. V. (2016). Psikhologicheskiy potentsial I barery innovatsionnoy aktivnosti subekta nauchno-pedagogicheskoi deyatelnosti [Psychological potential and barriers of innovation activity of the subject in scientific and educational activities]. Nauka I osvita Science and education, 11, 17-24 [in Russian].

5. Dudko, L. A. (2009). Struktura osobystisnoho i profesiinoho potentsialu konkurentospromozhnoho spetsialista v umovakh rynkovoi ekonomiky [The structure of personal and professional potential of a competitive specialist in terms of market economy]. Visn. Cherkas. un-tu. Cer. Ped. Nauky - Bulletin of Cherkasy University. Pedagogy, 165, 83-87 [in Ukrainian].

6. Kolosov, A. B. (2007). Kohnityvnyi resurs pidvyshchennia stresostiikosti kvalifikovanykh sportsmeniv (na prykladi studentiv VNZ fizkulturnoho profiliu) [The cognitive resource of increasing stress-resistance of highqualified athletes (through the example of students majoring in physical culture]. Extended abstract of Candidate's thesis. Kyiv: Tsentr. in-t pisliadyplom. ped. osvity APN Ukrainy [in Ukrainian].

7. Leontev, D. A. (2002). Lichnostnoe v lichnosti: lichnostnyy potentsial kak osnova samodeterminatsii [The personal in a personality: personal potential as the basis of self-determination]. Uchenye zapiski kafedry obshhej psihologii MGU im. M.V. Lomonosova - Scientific notes of the Department of General Psycology, Moscow State Lomonosov University, 1, 56-65. B. S. Bratus (Ed.). Moscow: Smysl [in Russian].

8. Lozhkin, H. V. (2010). Psykholohichnyi potentsial uspishnoi osobystosti [Psychological potential of a successful personality]. Proceedings of International scientific conference (pp. 31-35). M. L. Smulson, L. M. Zinchenko (Eds.). Kyiv. 2.

9. Manokha, I. P. (2001). Psykholohiia potaiemnoho «Ya» [Psychology of secret self]. Kyiv: Polihrafknyha [in Ukrainian]. the development of modern approaches to understanding the resources of implementing the innovative activity and its efficiency.

Further research will involve the study of psychological conditions of the personality's innovative potential development.

10. Markov, V. N. (2004). Lichnostnoprofessionalnyy potentsial kadrov upravleniya: psikhologo-akmeologicheskaya otsenka i optimizatsiya [Personal and professional potential of management staff: psycho-acmeologic evaluation and optimization]. Doctor's thesis. Moscow [in Russian].

11. Markozova, O. A. (2013). Samostiinist liudyny yak osnovna peredumova dosiahnennia zhyttievoho uspikhu [Independence of a person as a prerequisite of life success achievement]. Visnyk Natsionalnoi yurydychnoi akademii Ukrainy imeni Yaroslava Mudroho, Ser., Filosofiia, filosofiia prava, politolohiia, sotsiolohiia Bulletin of NLU "Law Academy named Yaroslav the Wise" the series of philosophy, political science and sociology, 4, 151-159 [in Ukrainian].

12. Melnyk, I. Yu., \& Boiarynova, K. O. (2012). Innovatsiinyi protses: naukovi pidkhody ta problemy realizatsii [Innovative process: scientific approaches and problems of realization]. Aktualni problemy ekonomiky ta upravlinnia - Actual problems of economics and management, 6. Retrieved from: http://probleconomy.kpi.ua/node/257 [in Ukrainian].

13. Miliaieva, V. R., Lebid, N. K, \& Breus, Y. V. (2013). Teoretychnyi analiz poniattia «potentsial osobystosti» [Theoretical analysis of the concept «potential of personality»]. Problemy suchasnoi psykholohii - Problems of modern psychology, 20, 405-415 [in Ukrainian].

14. Muzdybaev, K. (1983). Psikhologiya otvetstvennosti [Psychology of responsibility]. Leningrad [in Russian].

15. Murashko, I. V. (2010). Rozkryttia poniattia «osobystisnyi potentsial» ta yoho psykholohichnoi struktury [Disclosure of the concept "personal potential" and its psychological structure]. Aktualni problemy psykholohii: psykholohichna teoriia I tekhnolohii navchannia - Actual problems of psychology: theory of psychological and technology of education (Vol. 8), (pp. 196-205). S. D. Maksymenko, M. L. Smulson (Eds.). Kyiv: DP «Inforatsiinoanalitychne ahentstvo» [in Ukrainian].

16. Panasenko, N. M. (2016). Psykholohichni resursy osobystosti $v$ podolanni kryzy [The psychological resources of the individual to overcome crisis]. Retrieved from:

http://www.rusnauka.com/22_AND_2016/Psihologia/5_2 15311.doc.htm [in Ukrainian].

17. Rezvan, O. O. (2014). Refleksyvna samootsinka osobystykh resursiv studentiv [Personality resources reflective self-appraisal of students]. Pedahohichnyi 
protses: teoriia i practyka - The Pedagogical Process: Theory and Practice, 2, 9-13 [in Ukrainian].

18. Rohova, T. V. (2008). Resursnyi pidkhid v upravlinni pedahohichnym kolektyvom shkoly [Resource approach in the management of school teaching staff]. Zbirnyk naukovykh prats Kharkivskoho natsionalnoho pedahohichnoho universytetu imeni H. S. Skovorody Collection of research papers of Kharkiv national pedagogical university named after G. Skovoroda: pedagogy and psychology, 34. Retrieved from: http://www.nbuv.gov.ua/old_jrn/Soc_Gum/znpkhnpu_ped /2008_34/2.html [in Ukrainian].

19. Ckliaruk, A. V. (2013). Zovnishni ta vnutrishni faktory (resursy) simi, yak skladovi ii sotsialnopsykholohichnoho potentsialu [External and internal factors (resources) of family as components of its social and psychological capacity]. Problemy suchasnoi pedahohichnoi osvity. Pedahohika i psykholohiia - Problems of modern pedagogical education. Pedagogy and psychology, 39(4), 226-232 [in Ukrainian].

\section{ЛІТЕРАТУРА}

1. Gabora, L. (2013). Psychology of Creativity. In Elias G. Carayannis (Ed.) Encyclopedia of Creativity, Invention, Innovation, and Entrepreneurship (pp. 15151520). New Delhi, India: Springer.

2. Бодров В. А. Проблема преодоления стресса. Часть 2. Процессы и ресурсы преодоления стресса / В. А. Бодров // Психологический журнал. - 2006. № 2. - С. 113-123.

3. Великий тлумачний словник сучасної української мови / уклад. і голою. ред. В.Т. Бусел. - Київ; Ірпінь : ВТФ «Перун», 2003. - 1440 с.

4. Волянюк Н. Ю. Психологический потенциал и барьеры инновационной активности субьекта научно-педагогической деятельности / Н. Ю. Волянюк, Г. В. Ложкин // Наука і освіта. - 2016. - №11. - С.17-24.

5. Дудко Л. А. Структура особистісного і професійного потенціалу конкурентоспроможного спеціаліста в умовах ринкової економіки / Л.А. Дудко // Вісн. Черкас. ун-ту. Сер. Пед. науки. - 2009. - Вип. 165. - C. 83-87.

6. Колосов А. Б. Когнітивний ресурс підвищення стрес-стійкості кваліфікованих спортсменів (на прикладі студентів ВНЗ фізкультурного профілю): Автореф. дис... канд. психол. наук: 19.00.07 А. Б. Колосов; Центр. ін-т післядиплом. пед. освіти АПН України. - Київ, 2007. - 20 с.

7. Леонтьев Д. А. Личностное в личности: личностный потенциал как основа самодетерминации / Д. А. Леонтьев // Ученые записки кафедры общей психологии МГУ им. М.В. Ломоносова; под ред. Б.С. Братуся, Д.А. Леонтьева. - Вып. 1. - М. : Смысл, 2002. - C. 56-65.

8. Ложкін Г. В. Психологічний потенціал успішної особистості / Г.В. Ложкін // Успішність особистості: потенціал та обмеження: Тези доповідей Між-
20. Bilodid, I. K. (1976). Slovnyk ukrainskoi movy [Dictionary of the Ukrainian language]. (Vols. 1-11). Kyiv: Nauk. Dumka [in Ukrainian].

21. Bilodid, I. K. (1977). Slovnyk ukrainskoi movy [Dictionary of the Ukrainian language]. (Vols. 1-11). Kyiv: Nauk. Dumka [in Ukrainian].

22. Shtepa, O. (2012). Osoblyvosti psykholohichnoi resursnosti osib zriloho viku [The peculiarities of psychological resources adult persons]. Visnyk Lvivskoho universytetu. Seriia filosofski nauky - Bulletin of Lviv university. Philosophy, 15, 310-317 [in Ukrainian].

23. Shumpeter, Y. A. (1982). Teoriya ekonomicheskogo razvitiya (Issledovanie predprinimatelskoy pribyli, kapitala, kredita, protsenta $i$ tsikla konyunktury) [The Theory of Economic Development: reaesrching profits, capital, credit, interest and business cycle]. Moscow: Progress [In Russian].

24. Yagolkovskiy, S. R. (2011). Psikhologiya innovatsiy: podkhody, modeli, process [Psychology of innovation: approaches, models, processes]. Moscow: Higher School of Economics Publishing House [in Russian].

народної науково-практичної конференції (Київ, 18 березня 2010 р.); за редакцією М.Л. Смульсон, Л.М. Зінченко. - Київ, 2010. - С. 31-35.

9. Маноха І. П. Психологія потаємного «Я» / І. П. Маноха. - Київ: Поліграфкнига, 2001. - 448 с.

10. Марков В. Н. Личностно-профессиональный потенциал кадров управления : психологоакмеологическая оценка и оптимизация: дис. ... д-ра психол. наук : спец. 19.00.13 / В. Н. Марков. - М., 2004. $-453 \mathrm{c}$

11. Маркозова О.О.Самостійність людини як основна передумова досягнення життєвого успіху / О. О. Маркозова // Вісник Національної юридичної академії України імені Ярослава Мудрого. Сер. : Філософія, філософія права, політологія, соціологія. 2013. - № 4. - С. 151-159.

12. Мельник І.Ю. Інноваційний процес: наукові підходи та проблеми реалізації [Електронний ресурс] / І. Ю. Мельник, К. О. Бояринова // Актуальні проблеми економіки та управління: наукових праць молодих вчених. - 2012. - Вип. 6. - Режим доступу до pecypcy: http://probl-economy.kpi.ua/node/257.

13. Міляєва В. Р. Теоретичний аналіз поняття «потенціал особистості» / В. Р. Міляєва, Н. К. Лебідь, Ю. В. Бреус // Проблеми сучасної психології. - 2013. - Вип. 20. - С. 405-415.

14. Муздыбаев К. Психология ответственности / К. Муздыбаев. - Л. : Наука, 1983. - 240 с.

15. Мурашко I. В. Розкриття поняття «особистісний потенціал» та його психологічної структури / I. В. Мурашко // Актуальні проблеми психології: Психологічна теорія і технології навчання / за ред. : С. Д. Максименко, М. Л. Смульсон. - Київ: ДП «Інформ.-аналіт. агентство», 2010. - Т. 8. - С. 196-205. 
16. Панасенко Н. М. Психологічні ресурси особистості в подоланні кризи [Електронний ресурс] / Н. М. Панасенко. - Режим доступу до ресурсу: http://www.rusnauka.com/22_AND_2016/Psihologia/5_2 15311.doc.htm.

17. Резван О. О. Рефлексивна самооцінка особистих ресурсів студентів / О. О. Резван // Педагогічний процес: теорія і практика. - 2014. - Вип. 2. - С. 9-13.

18. Рогова Т. В. Ресурсний підхід в управлінні педагогічним колективом школи [Електронний ресурс] / Т. В. Рогова // Збірник наукових праць Харківського національного педагогічного університету імені Г. С. Сковороди «Педагогіка та психологія». 2008. - Вип. 34. - Режим доступу до ресурсу:

http://www.nbuv.gov.ua/old_jrn/Soc_Gum/znpkhnp u_ped/2008_34/2.html.

19. Склярук А. В. Зовнішні та внутрішні фактори (ресурси) сім’ї, як складові іï соціальнопсихологічного потенціалу / А. В. Склярук // Проблеми сучасної педагогічної освіти. Педагогіка і психологія. - 2013. - Вип. 39(4). - С. 226-232.
20. Словник української мови : в 11 т. / редкол.: I. К. Білодід (голова) та інші; Акад. наук Укр. РСР, Інт мовознавства ім. О. О. Потебні. - К. : Наук. думка, 1976 . - Т. 7. - 1976. -724 c.

21. Словник української мови : в 11 т. / редкол.: I. К. Білодід (голова) та інші; Акад. наук Укр. РСР, Інт мовознавства ім. О. О. Потебні. - К. : Наук. думка, 1976 . - T. 8. - 1977. $-928 \mathrm{c}$.

22. Штепа О. Особливості психологічної ресурсності осіб зрілого віку / О. Штепа // Вісник Львівського університету. Серія філософські науки. - 2012. Випуск 15.- С. 310-317.

23. Шумпетер Й. А. Теория экономического развития (Исследование предпринимательской прибыли, капитала, кредита, процента и цикла конъюнктуры): пер. с англ. / Й. А. Шумпетер. - М. : Прогресс, 1982. - 455 с.

24. Яголковский С. Р. Психология инноваций: подходы, модели, процессы / С. Р. Яголковский. - М. : НИУ ВШЭ, 2011. - 272 с.

\section{Наталія Юріївна Волянюк, доктор психологічних наук, завідувач кафедри психології $і$ педагогіки, Ольга Ігорівна Боковець, аспірантка кафедри психології і педагогіки, Національний технічний університет Украӥни «Киїський політехнічний інститут імені Ігоря Сікорського», проспект Перемоги, 37, м. Київ, Украӥна}

\section{ПСИХОЛОГІЧНА СТРУКТУРА ІННОВАЦИЙНОГО ПОТЕНЦААЛУ ОСОБИСТОСТІ}

Активні дослідження передумов, специфіки, детермінант розвитку інноваційного потенціалу особистості обумовлені практичною потребою людського суспільства у пошуку потенційних інноваторів, які здатні до створення нового у науці та техніці. У зв'язку з важливістю ролі інноваційного потенціалу виникає необхідність диференційованого розгляду його складових частин, які опосередковують взаємозв'язки між індивідуальними властивостями психіки суб'єкта та узгоджують його активність у відповідності із соціально й індивідуально значущими цілями. Відтак, інноваційний потенціал особистості аналізується відповідно з їх актуалізацією в технічно-орієнтованих і підприємницьких проектах. Цілком ймовірно, що структура інноваційного потенціалу об'єднує ті психічні утворення, які здатні організовувати і координувати різні форми взаємодії суб'єкта з реальністю. В процесі розвитку уявлень про інноваційний потенціал в ньому виділяють інтелект, потреби і мотиви, духовні та ціннісні утворення, емоції і волю. Однак, й дотепер специфіка інноваційного потенціалу досліджена досить фрагментарно. Мета статті полягала у виявленні структурних компонентів та обгрунтуванні психологічної структури інноваційного потенціалу особистості. Для вирішення поставлених завдань було використано комплекс методів, як-от: аналіз, синтез, порівняння, узагальнення та систематизація сучасної наукової літератури з проблеми формування та розвитку інноваційного потенціалу особистості. Операціоналізацію концепту «інноваційний потенціал особистості» здійснено крізь призму двох феноменів - «інновація» та «потенціал». Виявлено, що у психології «інновація» інтерпретується як результат творчості, який полягає у розкритті потенційних можливостей особистості та створенні нових оригінальних ідей. Потенціал, маючи два актуалізовані стани, вміщує у себе сукупність внутрішніх та зовнішніх ресурсів. Внутрішні ресурси забезпечують цілісний процес життєдіяльності особистості, зовнішні - обумовлюють успішність процесів індивідуалізації, соціалізації та професіоналізації. Еклектичне поєднання двох феноменів уможливило розгляд та розуміння інноваційного потенціалу особистості як динамічної інтегративної сукупності соціально-психологічних характеристик особистості, що визначають ії здатність до створення, освоєння та використання нового. Теоретично обгрунтовано доцільність виокремлення наступних структурних компонентів інноваційного потенціалу особистості: «середовищні» (суспільні, матеріальні та духовні) та особистісні (мотиваційноціннісні, когнітивні, креативні, емоційно-вольові та регулятивні) ресурси.

Ключові слова: інновація, потенціал, ресурс, особистість, структура.

Submitted on January, 10, 2017

Reviewed by Doctor of Psychology, prof. H. Lozhkin 